\title{
CHALLENGES OF PUBLIC PROCUREMENT IN EU FUNDED PROJECTS
}

\author{
Marko Šostar, ${ }^{*}$ Ana Marukić**
}

Received: 21. 4. 2017

Review

Accepted: 20. 10. 2017

UDC 336.27:005.8(4-6 EU)

\begin{abstract}
Membership in the European Union implies adjustment of EU projects to the rules of Structural Funds, but also adoption of legal regulations, thus influencing the process of implementation of the public procurement in EU funded projects. Each successful applicant who expressed the need for procurement of goods, services and works of a certain value, must respect the principles of public procurement. Irregularities in the procurement process can lead to the failure of returning the EU funds even several years after the end of the project. Therefore, the knowledge and proper implementation of public procurement is
\end{abstract}

\section{INTRODUCTION}

In 2013, Croatia became a full member of the European Union, which has introduced a substantial change in terms of the use of EU funds. Structural funds became available to Croatia, replacing the previous Instrument for Pre-Accession Assistance - IPA that helped implement political, economic and institutional reforms necessary for joining the EU and for effective programming, the main precondition for the correct implementation of each project. In order to obtain information about the current absorption capacity of the public procurement liable parties, and to identify key obstacles that stakeholders face in procurement procedures, the research was conducted by surveying 30 entities that are subject of public procurement in Croatia. Research results imply the poor quality of public procurement in the implemented projects, which often results in financial corrections, disapproving project reports, etc.

Keywords: Public procurement, PRAG, Law on Public procurement, EU projects, EU funds, financial corrections

implementation and management of Structural and Cohesion Funds (Belić et al, 2008). Using EU funds raises a lot of question about the type and quality of funded projects: Which projects are good? What kind of projects get grant on calls for proposals? Is it enough to write a project that meets the technical requirements of the proposal? Is the quality of the project essential for getting a grant? Are well written projects always successful in the implementation? (Maletić

* Marko Šostar, PhD., Head of Department for European integrations, City of Požega, Trg Svetog Trojstva 1, 34 000 Požega, e-mail: marko.sostar.hr@gmail.com, telephone: +385 34312 585, fax: +385 34311344

** Ana Marukić, MA, Project management Associate at City of Požega, Department for European integrations, Trg Svetog Trojstva 1, 34000 Požega, e-mail: ana.marukic@gmail.hr, telephone: +385 34312 586, fax: +385 34 311344 
et al, 2016). There is no single answer to these questions, but it is important to have clear objectives, realistic expectations, well defined activities and well planned costs because all of the above mentioned may have either a direct or an indirect impact on the preparation of projects, and later on the quality of the project implementation. Management of the implementation of EU projects is a very complex and administratively demanding task, and requires good knowledge of the European and national rules in all phases of the project cycle.

Public procurement is a very important part of the project implementation process and it must be carried out in compliance with the established principles. Otherwise, it is questionable whether the approved amount will be successfully used, since all irregularities related to public procurement procedures result in financial corrections of up to $100 \%$ of the contracted amount. The main purpose of this paper is to indicate the most common mistakes that occur in the procedure itself and to identify the key obstacles encountered by public contractors on the basis of research.

\section{EU PROJECT MANAGEMENT}

All projects, including those funded by the EU, consist of a series of activities whose purpose is the achievement of clearly specified objectives within a certain time period and with a specific budget. Good preparation and the involvement of all relevant stakeholders, both in the planning and in the implementation stage of the project, is the basis for successful implementation of each project. Good coordination and communication among all project partners, and the support of management is key to successful implementation (Maletić et al, 2016). Although filling the application forms is rather challenging, it is a good exercise for strategic planning. It also obliges applicants to seek partners and expand their networks to other countries and different types of organizations. Almost every project that has a European dimension and / or may be associated with EU funds in the country, should find a suitable program for financing (Omondi et al, 2005).

\subsection{First steps after signing the contract}

After the contract is signed, it is necessary to establish the management structure of the project. Each coordinator applies a unique project management system based on personal experience or best practices. In order to fulfil the project requirements for successful implementation, it is necessary to achieve coordination and the involvement of financial department in the implementation of the project system.

Management activities involve good time management for each year of implementation, coordination of the implementation of project activities, communication with the competent authorities, quality control of direct project results, planning trips and events, planning and implementation of promotional activities and ensuring visibility of the project. Human resource management involves selection of the project manager with clear responsibilities, planning assignments for the project team with strict schedule, planning and calculation of the effective working days and hours in one year of the project, planning project team meetings, etc. Process management includes risk management, responsibility for public procurement procedures: preparing documentation, participation in the work of the committee for evaluation, monitoring implementation of the contracts, monitoring project progress against planned objectives and expected results, documenting project 


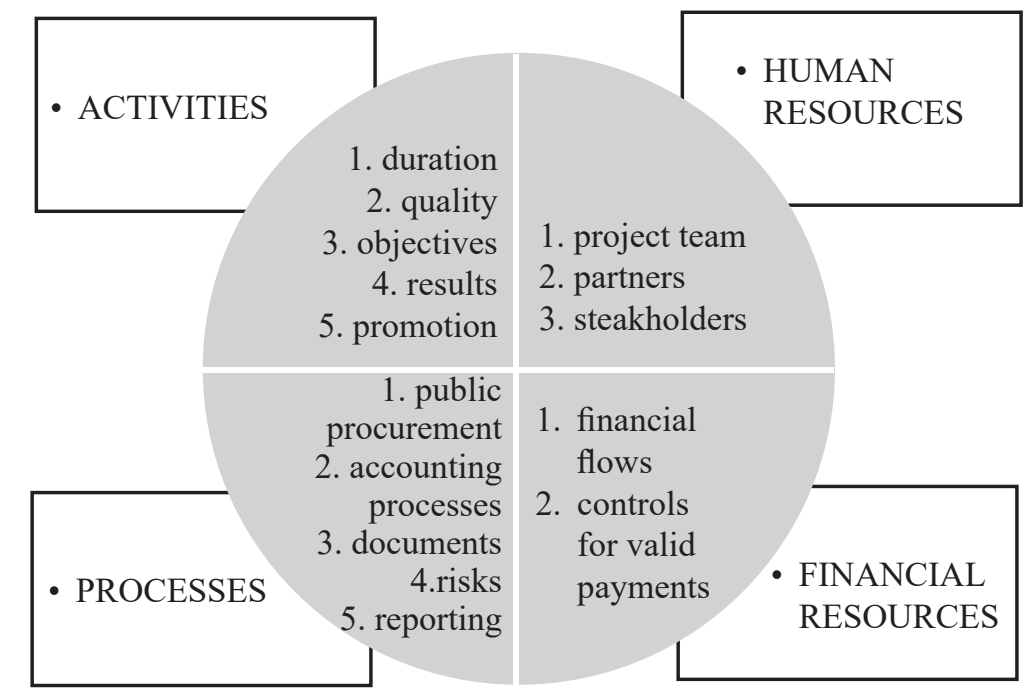

Source: Maletić et al, 2016.

\section{Figure 1: Managing during the project cycle}

activities etc. Financial management refers to monitoring the eligibility of expenses, preparation of narrative and financial reports, accounting records of costs in the institution of the beneficiary, opening and maintenance of sub-account for the project (if applicable), the responsibility for the financial management of the project budget, etc.

At the beginning of the implementation of an EU project, it is advisable to organize a meeting of all project partners and clearly allocate roles and responsibilities for each activity separately. It is necessary to make the procurement plan in particular following the schedule of activities, as well as a detailed action plan with clear deadlines.

\section{PUBLIC PROCUREMENT IN EU FUNDED PROJECTS}

When concluding agreements for the project costs, the grant beneficiary should collect competitive offers from potential bidders and award the contract to the bid offering the best price-quality ratio. The procedure needs to be guided by the principles of transparency, equal treatment, non-discrimination, and it is necessary to provide the conditions that will not lead to a conflict of interest. Public procurement at the EU level is considered one of the key instruments of the Europe 2020 Strategy for smart, sustainable and inclusive growth. The improvement and introduction of new public procurement rules at EU level aims to a more strategic use of public procurement to achieve the common goals of society, which ensures the most efficient use of public funds (Fresl, 2016). Before Croatia's accession to the $\mathrm{EU}$, public procurement procedures were conducted in accordance with Practical Guide to Contract procedures for EU external actions - PRAG. After accession, all public procurements, including those in the EU projects, are being implemented in accordance with primary and secondary legislation of the Republic of Croatia. PRAG explains the contracting procedures applying to all EU external actions financed 
from the EU general budget (the EU budget) and the European Development Fund (EDF) (European Commission, 2016.). Croatian Public Procurement Act applies to the projects financed by the Structural and investments funds. If, however, a legal or natural person is not subject to the Public Procurement Act, the same is considered as an NPO - Non - Purchasing Organization (Omondi et al, 2005.). For those who are not liable to the Public Procurement Act, but still participate in the implementation of projects financed from the ESI Funds in the Republic of Croatia, general principles for subcontracting services, goods and works are applied.

Specific rules for EU projects are characterized by legal minimalism, which is manifested in the need for understanding and proper interpretation of the basic
Lack of understanding of the principles of public procurement or their misinterpretation can jeopardise the eligibility of project costs. Financial corrections at Member States can take enormous scale, e.g. in 2012 Spain had more than 2 billion euros of financial correction (Zrinušić, 2014). The larger the project, the greater the financial impact leverage on the beneficiaries of EU funds.

\subsection{Public procurement in EU funded projects - before and after EU accession}

When tendering for projects financed from pre-accession funds of the $\mathrm{EU}$, candidates are obliged to give up the national public procurement regulations and follow the principles of the PRAG. This guide contains the information about all the rules

Table 1: Limits supply and the type of procedure according to PRAG

\begin{tabular}{|l|l|l|}
\hline \multirow{4}{*}{ Services } & Value of the procurement & Type of procedure \\
\cline { 2 - 3 } & $>300.000$ EUR & Restricted tenders \\
\cline { 2 - 3 } & $300.000-20.000$ EUR & Competitive negotiated procedure \\
\cline { 2 - 3 } Goods & $<20.000$ EUR & Single tender \\
\hline \multirow{5}{*}{} & Value of the procurement & Type of procedure \\
\cline { 2 - 3 } & $>300.000$ EUR & International open tender \\
\cline { 2 - 3 } & $300.000-100.000$ EUR & Local open tender \\
\cline { 2 - 3 } & $100.000-20.000$ EUR & Competitive negotiated procedure \\
\cline { 2 - 3 } & $<20.000$ EUR & Single tender \\
\hline \multirow{4}{*}{ Works } & Value of the procurement & Type of procedure \\
\cline { 2 - 3 } & $>5.000 .000$ EUR & International open tender \\
\cline { 2 - 3 } & $5.000 .000-300.000 \mathrm{EUR}$ & Local open tender \\
\cline { 2 - 3 } & $300.000-20.000 \mathrm{EUR}$ & Competitive negotiated procedure \\
\cline { 2 - 3 } & $<20.000$ EUR & Single tender \\
\hline
\end{tabular}

Source: European Commission, PRAG, 2016.

principles of public procurement. The rules of transparent and precise procurement have a strong impact on the overall success of the project. Croatian experience, but also experience of the entire European Union, shows that the correct interpretation of the principles of public procurement is an extremely complex and challenging task. of public procurement, it determines what type of competition applies, and it explains how to evaluate and select bids. PRAG rules are considered a good international practice in the implementation of procurement procedures in EU projects.

According to the PRAG rules, the estimated procurement value determines the 
procedure to be carried out. All public procurement under 20.000 EUR are carried out on the basis of a single tender, while all other applicable procedures are based on the PRAG rules. After Croatian accession, national legislation applies to all public procurement. The new Public Procurement Act, which has been in force since January 2017, prescribes the value ranges which the contracting authorities must comply with (Table 2.).
All EU Member States were obliged to harmonize their laws and regulations with the new directives on public procurement (Directive 2014/24/EC and Directive 2014/25/EU, Public procurement portal, 2016) by April 2016. In the area of public procurement, Croatia has to adjust to the new system which is characterised by an electronic submission of offer, Single European document for procurement, and to the most economically advantageous tender

Table 2: Value ranges and the corresponding type of procedure according to the national legislation of the Republic of Croatia

\begin{tabular}{|c|l|l|}
\hline \multirow{2}{*}{$\begin{array}{c}\text { Goods and } \\
\text { services }\end{array}$} & Value of the procurement & Type of procedure \\
\cline { 2 - 3 } & $\geq 27.000$ EUR & Single tender \\
\hline \multirow{2}{*}{ Works } & $<67.000$ EUR & Public procurement procedures \\
\cline { 2 - 3 } & $\geq 67.000$ EUR & Single tender \\
\hline
\end{tabular}

Source: Public Procurement Act of the Republic of Croatia, NN 120/16

Comparison between the PRAG public procurement rules and the rules of the national law indicates that the application of national legislation simplifies the procedure. While PRAG prescribes a different type of procedure for each amount, the Public Procurement Act allows public buyers to choose whether the process is to be open or restricted, regardless of the value of the purchase. It is very important to comply with the prescribed procurement procedures in accordance with the procurement values in Table 2. If the value of a good or service is at the value limit, it is always better to choose a more transparent procedure. It is necessary to keep in mind that the deliberate planning of a number of smaller purchases is strictly forbidden. This also refers to the avoidance of merging multiple items from the project budget into one procurement procedure in order to facilitate the implementation of simpler procedures that do not require public procurement. criteria as the leading criteria for selection offer. The intention is to achieve less administrative burden for all stakeholders in the procurement process, to strengthen the competition and to achieve the best value for money. The upcoming changes create better conditions both for public buyers and bidders. Decrease of administrative barriers and easier access to tenders cannot produce results if key stakeholders of public procurement do not follow changes in the field of public procurement and do not invest in their knowledge.

\subsection{Public procurement in EU member states - statistical review according to selected indicators}

This chapter shows public procurement in the EU member states using statistical data, according to the following indicators: (1) one bidder, (2) no calls for bids, (3) cooperative procurement, (4) award criteria and (5) decision speed. 


\section{Indicator (1) - One bidder}

This indicator reflects several aspects of procurement, including competition and bureaucracy. It is better when more providers bid for the public tender, which means that public buyers have more options and can get better value for money. This indicator measures the proportion of contracts awarded where there was only one bidder (in fact the indicator does not include framework agreements because they have different reporting forms).

Public procurement tenders with only one bidder put Croatia on top in the EU (51\% in 2014) but since then the numbers have been decreasing. Croatia is followed by Poland, Hungary and Slovakia, with an average between $30 \%$ and $40 \%$. The data also indicate that more than half of the contracts have been concluded in Croatia in an uncompetitive environment. Such data raises the question of the correctness of the criteria set out in the procurement documentation. Are they discriminating? Do they allow a large number of applicants to apply at all?

\section{Indicator (2): No calls for bids}

This indicator measures the proportion of public procurement procedures where the bidders negotiated without a call for bids.

In 2013, Croatia achieved the highest rate of $32 \%$ of public procurement contracted without a call for bids. However, the same indicator was significantly reduced to $9 \%$ in 2014 and 2015. Other countries with a similarly high percentage (about 23\%) of public procurement of the same type (without the participation of other bidders) are Cyprus and the Czech Republic. This information also speaks of a large percentage of direct contracting when purchasing goods, services and works. It is also possible that these data imply a potential artificial sharing of the procurement, mentioned in Chapter
3.1. The purpose of the public procurement is to get the best value for money, and with such inadmissible procedures that goal is most often not fully achieved.

\section{Indicator (3): Cooperative Procurement}

This indicator shows how often public bidders buy joint in the joint venture. This often leads to better prices but also creates an opportunity for the exchange of knowledge or know-how.

In 2014, Malta had the most public procurements that involved aggregation (71\%) but it is interesting that in 2015 it had none at all. In that period, Croatia had less than $10 \%$ of such purchases.

\section{Indicator (4): Award criteria}

This indicator shows how public buyers award bidders for the conclusion of public contracts - based on the lowest price or the quality as a selection criteria. The chart below shows the percentage of public procurement based on the lowest price.

Most member states make public procurement selection based on the lowest price criteria. Croatia and Malta make more than $90 \%$ of such public procurement, France only 5\%, and the United Kingdom $8 \%$, which makes the latter two the countries with the lowest values of that indicator.

\section{Indicator (5): Decision speed}

"Decision speed" measures the mean decision period. This is the time between the deadline for receipt of offers (or requests to participate) and the award of the contract (European commission, 2015). Lengthy procedures are bad because they are expensive and cause uncertainty for both the public buyers and the companies. To provide comparability only notices under the open procedure are considered. 
Table 3: The most significant risks of corruption and measures to increase transparency and accountability in public procurement procedures

\begin{tabular}{|c|c|}
\hline The most significant risks & $\begin{array}{l}\text { Measures to increase transparency and } \\
\text { accountability }\end{array}$ \\
\hline $\begin{array}{l}\text { Unnecessary investment that has no } \\
\text { value to society. } \\
\text { - } \\
\text { Fverestimated required amounts. } \\
\text { procurement implementation procedures } \\
\text { (based on the estimated values) } \\
\text { Subdividing the value of procurement } \\
\text { with intention of avoiding application of } \\
\text { the procurement process. } \\
\text { Selection of the negotiating procedure } \\
\text { without prior publication contrary to the } \\
\text { prescribed conditions. } \\
\text { Tender documentation is discriminatory } \\
\text { and it favours a specific business entity } \\
\text { (e.g. conditions and requirements that } \\
\text { are not directly related to the subject of } \\
\text { procurement). } \\
\text { Type designation of the goods which } \\
\text { puts a specific manufacturer into a } \\
\text { more favourable position. Technical } \\
\text { specifications are prepared by potential } \\
\text { bidders, whereby it is difficult to ensure } \\
\text { equal position of other bidders. } \\
\text { Technical specifications are made in a } \\
\text { way that its terms can be fulfilled only } \\
\text { by a particular economic operator. }\end{array}$ & $\begin{array}{l}\text { Publication of the buyer profile. } \\
\text { Publication of the annual procurement plan on } \\
\text { the website, so that the interested economic } \\
\text { operators, especially small and medium- } \\
\text { sized enterprises, could timely prepare for } \\
\text { participation in competitions. } \\
\text { Obligation to keep verifiable records of all } \\
\text { steps in the preparation and implementation of } \\
\text { procedures, which, if there is a suspicion of a } \\
\text { conflict of interests or corrupt activity, can be } \\
\text { more easily identified. }\end{array}$ \\
\hline \multicolumn{2}{|c|}{2 Implementation of Public Procurement } \\
\hline The most significant risks & $\begin{array}{c}\text { Measures to increase transparency and } \\
\text { accountability }\end{array}$ \\
\hline $\begin{array}{l}\text { Conclusion of cartel agreements in } \\
\text { order to influence the outcome } \\
\text { Exclusion of tenders which satisfy the } \\
\text { conditions of competition or accepting } \\
\text { the offer, which would have to be } \\
\text { excluded. }\end{array}$ & $\begin{array}{l}\text { - Creating of regular internal reports on all } \\
\text { phases of preparation and implementation of } \\
\text { competition. } \\
\text { Establishing rules for reporting irregularities. } \\
\text { - Separating of functions within the } \\
\text { implementation of the public procurement } \\
\text { procedure (for example, the same person } \\
\text { cannot be responsible for both the preparation } \\
\text { process and control of the execution of } \\
\text { contracts). } \\
\text { If the purchaser contacts any bidder, all other } \\
\text { bidders shall be notified in a verifiable way. } \\
\text { Additional disclosure of all relevant documents } \\
\text { on the website of the contracting authority. }\end{array}$ \\
\hline
\end{tabular}




\begin{tabular}{|l|l|}
\hline \multicolumn{1}{|c|}{3 Realization of the contract } \\
\hline \multicolumn{1}{|c|}{ The most significant risks } \\
- $\begin{array}{l}\text { Non execution of the contract, } \\
\text { particularly in terms of its quality, price } \\
\text { and service. }\end{array}$ \\
$\begin{array}{l}\text { Altering important terms of the contract } \\
\text { accountability }\end{array}$ \\
$\begin{array}{l}\text { that are contrary to the implemented } \\
\text { procedure of public procurement (price, } \\
\text { technical content, completion date, etc). }\end{array}$ \\
$\begin{array}{l}\text { Concluding contracts for small } \\
\text { quantities of goods, works or services } \\
\text { and then making additional purchases } \\
\text { from the same economic entity without } \\
\text { a call for tenders. }\end{array}$ \\
\hline
\end{tabular}

Source: Public procurement portal, Prevention of corruption and conflicts of interest, 2017

Greece had the longest duration of decision making, which in 2015 took an average of 287 days. Italy, Malta, Bulgaria and Slovakia had the duration of the decision making of 120 days.

\subsection{Public procurement problems - public procurement as a corruption "hot spot"}

Public procurement is a very specific market characterised by a large volume of transactions, the complexity of roles of all the stakeholders and risk pricing in conditions of limited competition. Imperfections occur in the market of public procurement, particularly monopoly over and asymmetry of information. In the field of procurement it is possible to commit unlawful acts, especially criminal acts of corruption, a very complex social and criminal justice problem, especially in transition countries (Ljubanović, Britvić-Vetma, 2011). According to the legal opinion of the Court of Justice of the European Union one of the most important principles of public procurement requires that all bidders/candidates are treated equally. Public procurement system must provide cost-effective and efficient procedures and rational spending of money in accordance with the basic principles of public procurement whenever the Public Procurement Act or special rules for projects financed from EU funds are applied.

Many studies of the European Commission show that none of the EU Member States is immune to corruption in public procurement and therefore it can be said that the public procurement is corruption "hot spot". Therefore, effort should be put into increasing the transparency of the process and procedures in order to help prevent corruption and malicious acts. According to the European Commission statistics, more than three quarters of European citizens (94\% in Croatia) believe that widespread corruption is present in their country. 4\% of Europeans $(6 \%$ Croats) were asked to pay a bribe, or in some way witnessed corruption. $81 \%$ of Croatian companies believe that corruption creates obstacles in business (European Commission, Anti fraud report 2014). Croatia has recently invested substantial efforts in fighting corruption. It seems, however, that the focus is on fighting, rather than the preventing it. 
One of the main objectives in the implementation of projects financed by EU funds is to ensure effective internal and external communications related to the mechanisms of prevention and reporting of irregularities and frauds. Each project is preceded by a long process of preparation, with a bureaucratic and very detailed control system that is trying to ensure thatEU taxpayers' money is invested efficiently. Incorrect usage of EU funds causes damage to European taxpayers or citizens. There are several common procedures related to irregularities: procedures for warning about abnormalities, procedures for identifying irregularities and procedures for reporting irregularities. Reporting of irregularities is expected from each user and from all officials in the system of implementation of EU projects, regardless of the size or character of irregularities.

Errors in the implementation of public procurement form a great share of all irregularities related to the use of EU funds. One of the mayor public procurement issues, that automatically leads to $100 \%$ withdrawal of funds, is the violation of the Principle of equal treatment of all bidders and discriminatory approach, where particular bidders are given preference and tenders are tailored for them by creating artificial conditions in bidding documents that favour a small number of bidders. In the public procurement documentation, artificial conditions are strictly forbidden, yet proving it was a deliberate activity is very difficult. In public procurement tenders it is often the case that one bidder benefits by lowering prices up to $70 \%$ below all the value criteria, which most often results in unpaid work or other form of illegal behaviour. Therefore, while the national budgets lack funds, large sums of money end up in the accounts of the privileged, while common citizens pay the price. Public procurement, in general, is often the largest weight of an economy because it is a high corruption risk area where the success and realization of numerous EU projects are in question. Corruptive behaviours in the public procurement often end up by displeased bidders filing an appeal, thus extending the deadlines of the procedure until the final decision is made. Consequently, the deadlines for the implementation of certain project activities defined in the "timeline" of the project will be delayed, and the project holder will face financial corrections. It directly blocks and delays the use of available EU funds, while these have to be spent within the given deadlines or returned to the European budget, which is a high risk for every project applicant. In each tender for any EU project under the eligibility criteria for the applicant, it is explicitly stated that the applicant or person authorized to represent the applicant must not be legally convicted, inter alia, of abuse of public procurement, fraud, bribe and bribe procedures. If proven to be, the approved funds for the submitted projects must be returned and the applicants also bear criminal and material responsibility. Applicants who have been proved to have abused of public procurement procedures are denied the right to apply for further EU tenders. Procedures of public procurement lacking transparency often results in poor quality of the goods / services / works procured leading to the delay of the realization of the project may or, even worse, its cancellation. Each project is subject to a series of controls for several years even after the project closure. If, after the project closure, there is a proof of illegal misbehaviour in public procurement procedures, the perpetrators who committed the offense end up on the "black lists" for future tenders. 


\section{PUBLIC PROCUREMENT IN CROATIA}

Thirty entities that are subject to public procurement in Croatia have been surveyed in order to obtain information about the current absorption capacity of the public procurement buyers and to identify the key obstacles that stakeholders encounter in procurement procedures. Survey data ernment units and $13 \%$ of business support institutions (development agencies, business incubators ...).

According to the Figure 2, most of the entities involved in survey in 2016 have contracted public procurements of less than 670.000 EUR (57\%), while the rest (43\%) contracted public procurements of more than 2.660.000 EUR.

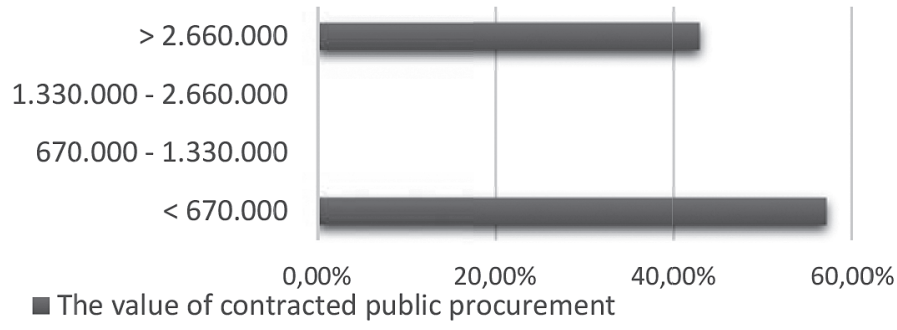

Source: Author's survey, 2017

Figure 2: The value of contracted public procurement in 2016, in EUR

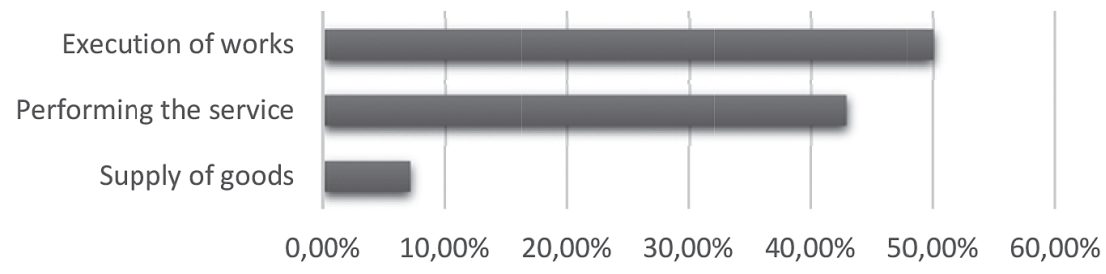

Most common purpose of conducting public procurement procedures

Source:Author's survey, 2017

Figures 3: Most common purpose of conducting public procurement procedures

are presented for 2016. Figures 2 to 8 present the values obtained by the survey which consisted of 12 questions and was addressed to 40 entities. The response rate was $75 \%$. The study included more than $50 \%$ of entities governed by public law (e.g. Croatian Employment service, State Offices for Administration etc.), $33 \%$ local (regional) gov-
Most of public procurement was carried out for the purpose of execution of works $(50 \%)$ followed by the provision of services $(43 \%)$ and finally the supply of goods $(7 \%)$.

According to the previous solution, the public buyers were able to choose between two selection criteria: the lowest price and the most economically advantageous tender. 


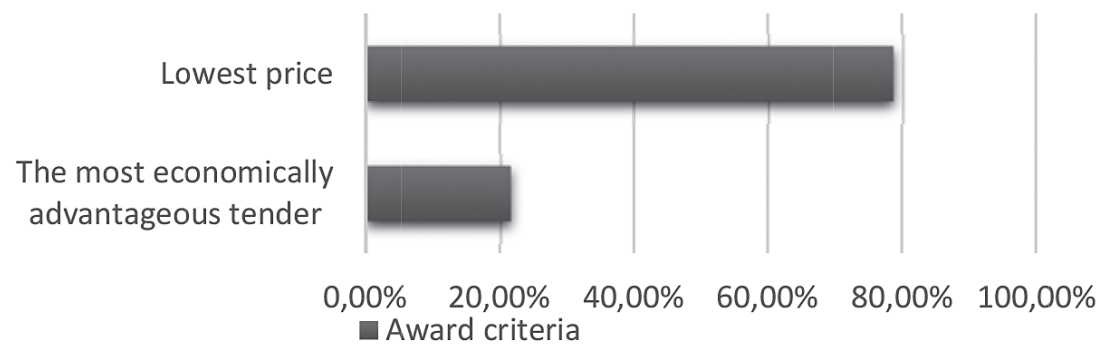

Source: Author's survey, 2017

Figure 4: Award criteria

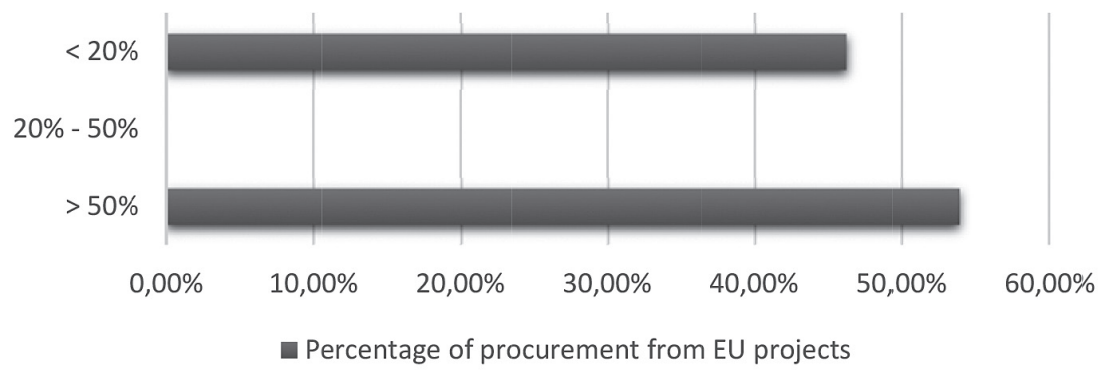

Source:Author's survey, 2017

Figure 5: Percentage of procurement from EU projects

The consequence of such free selection went in favour of the lowest prices - according to statistical indicators so far the public buyers applied exclusively the lowest price as the criterion in $98 \%$ of procedures (Ministry of Economy, Small and Medium Business and
Trade, 2016.). The same is confirmed by the data in Figure 4, where 78\% of respondents confirmed that the most common selection criterion was the lowest price. These results generate insolvency and the collapse of the market.

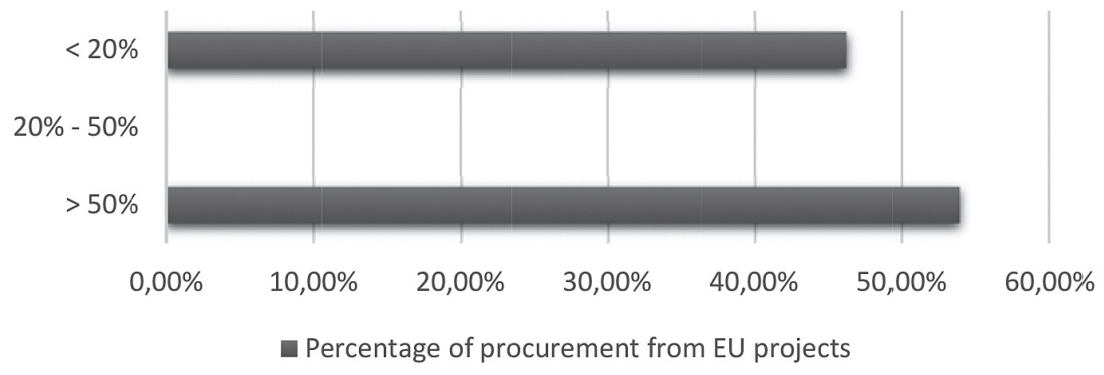

Source: Author's survey, 2017

Figure 6: The most common problems during the public procurement procedure 
More than $54 \%$ of respondents said that most of their public procurement was related to EU projects (over 50\%).

The most common problem that respondents emphasize are insufficient human resources for public procurement in institutions. This problem occurs because most organizations usually employ only one or maximum two persons responsible for the implementation of all procedures, both related to EU projects and "regularly" financed from its own funds, which often leads to overload with a large number of procedures to prepare and implement. Significant problems in public procurement procedures are identified in the area of planning and implementation which can be linked to the problem of latency of most of the calls for proposals for EU projects, so public buyers have difficulty to anticipate and provide sufficient funds for the realization of the contract at the right time. The study also identified the problem of improper development and preparation of tender documentation and lack of education. This problem is to be solved through the introduction of Europe's single documentation on procurement (ESDP), which will replace the submission of multiple documents in procurement procedures (European commission, 2017). Thus only the selected bidder would be obliged to submit a complete physical documentation. The European
Commission predicts that this approach will reduce the administrative burden for economic operators to $80 \%$. This simplification goes hand in hand with encouraging public buyers to divide the procurement procedures in small groups so that small economic operators would be able to tender.

Only $7 \%$ of respondents have ever carried out a green public procurement indicating there is lack of such procurements in Croatia. The implementation procedures of green public procurement in the EU project is very important in the area of project contribution to sustainable development and environmental protection whereby EU is trying to encourage all applicants to carry out the procurement of goods, services and works that have a lower impact on the environment. That is the reason why buyers will soon be additionally encouraged to pay greater importance to criteria of quality, environmental issues, social features and innovations, while still taking into account the price and the cost of the life cycle of procurement.

Under the new Law on public procurement of the Republic of Croatia which has been in force since $1 / 1 / 2017$, the criteria for selection of bids in public procurement procedures is economically advantageous tender (NN 120/16). The most economically advantageous tender is determined on the

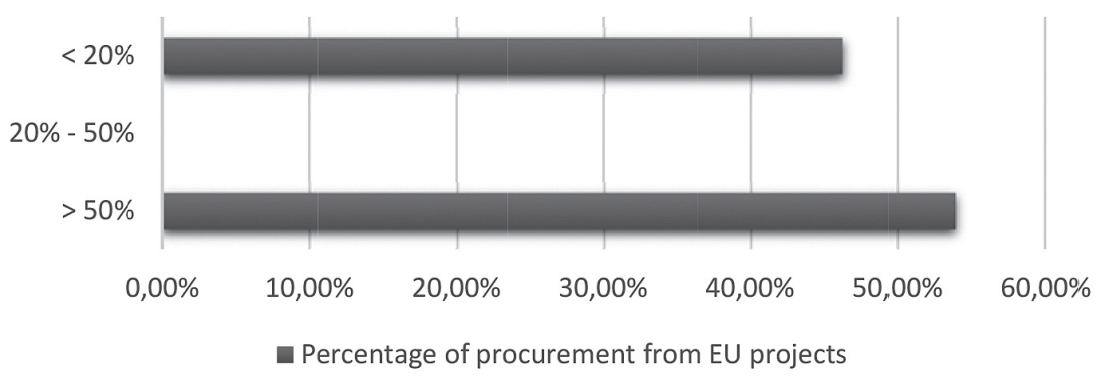

Source: Author's survey, 2017

Figure 7: Have you ever carried out a green public procurement? 


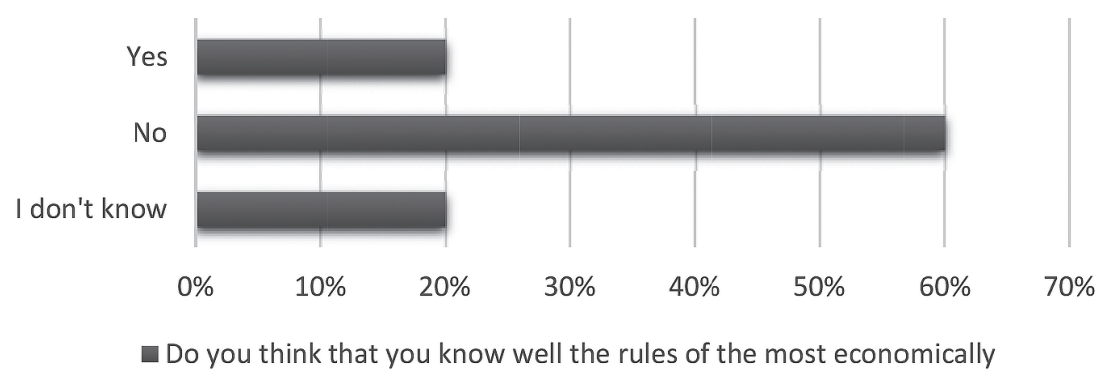

Source: Author's survey, 2017

Figure 8: Do you think that you are well informed about the rules of the most economically advantageous tender?

basis of price or cost, using the approach of cost-effectiveness, as well as the cost of life cycle cost (LCC), and may include the best ratio between price and quality, qualitative environmental and / or social aspects related to the subject matter of the concerned public contract (Maletić et al, 2016). According to the new law public buyers must understand the subject of public procurement in order to devise a scoring system that fits this model of evaluation and selection of received bids. If public buyers do not know enough about the criteria based on which they will allocate funds for works, goods and services, there is a risk that this model will not achieve its goal, and that it will not get the best value for money. The survey shows that $60 \%$ of respondents believe that they are not sufficiently familiar with the rules of the most economically advantageous offer. This suggests the need for intervention among public buyers by organising educations, workshops, panels, etc. on the implementation of the new law.

\section{CONCLUSION}

The main purpose of the EU projects is to develop the economy and to increase the standard of living of all EU member states, under the condition of free competition and transparency in the usage of social resources. To make public procurement procedures as efficient as possible, it is important to eliminate administrative or technical causes of weakness. For all key stakeholders of public procurement it is important to keep update with the changes in the field of public procurement. Decision makers in management positions need to be informed in order to understand the stratification of public procurement and to be able to make the necessary business decisions. Identifying the specific problems within the organization is an excellent starting point for establishing an efficient public procurement system and public procurement strategy. Organizations that have a clear picture of goals they want to achieve through public procurement and are familiar with the framework and limitations of achieving this goal see public procurement as a challenge, not a problem.

The research presented in this paper shows that respondents conducted more than $50 \%$ of its public procurement in EU projects, but also almost none of them ever carried out a green public procurement, they are not sufficiently familiar with the rules of the most economically advantageous offer, they cited lack of education, difficulties in planning and preparation of projects and preparation of documentation. This implies the poor quality of public procurement in 
the implemented projects, which often results in financial corrections in the project, disapproving reports and similar. Irregular and poor quality implementation of public procurement significantly aggravates the implementation of EU projects. Finally, these problems prevent the realization of the overall objective of the project. EU projects represent our future in the eyes of those

\section{References}

1. Arrowsmith, S., Bordalo Faustino, P., Heuninckx, B., Treumer, S., Fejo, J. (2010): EU Public procurement law, University of Nottingham

2. Belić, M., Čorić, G., Peurača, B., Stojanović, G., Tonč, A. (2008): EU Fondovi - Vodič kroz europske fondove 2008.-2013., Novum d.o.o., Zagreb

3. Budak, J. (2016): Korupcija u javnoj nabavi: trebamo li novi model istraživanja za Hrvatsku?, Ekonomski pregled, Vol.67 No.4

4. European commission (2015): Limiting the temptation for corruption in public procurement, http://ec.europa. eu/growth/tools-databases/newsroom/ cf/itemdetail.cfm?item_id=8594, [Accessed 22.2.2017.]

5. European commission (2014): $E U$ anti-corruption report, Brussels, https:// ec.europa.eu/home-affairs/sites/homeaffairs/files/e-library/documents/policies/organized-crime-and-human-trafficking/corruption/docs/acr_2014_en.pdf, [Accessed 3.4.2017.]

6. European commission (2016): PRAG Practical Guide, http:// ec.europa.eu/europeaid/prag/document.do?nodeNumber $=1, \quad$ [Accessed 10.12.2016.]

7. Europska komisija (2014): Izvješće o suzbijanju korupcije u EU-u, Annex 11, Bruxelles, https://ec.europa.eu/home- who know how to design a project, how to implement it and how to achieve goals and ensure sustainability. Non-compliance with the rules of public procurement has always been and remains a major source of "financial correction" in EU projects, so it is important to permanently work on solving this problem.

affairs/sites/homeaffairs/files/whatwe-do/policies/organized-crime-andhuman-trafficking/corruption/anti-corruption-report/docs/2014_acr_croatia chapter_hr.pdf, [Accessed 3.4.2017.]

8. European commission (2015): The EU single market, Public procurement, [Accessed 26.12.2016.]

9. Europska komisija (2017): Europska jedinstvena dokumentacija o nabavi, https://ec.europa.eu/tools/espd/ filter?lang=hr\#, [Accessed 3.4.2017.]

10. Fresl, A. (2016): Spremnost organizacija za primjenu novih direktiva u javnoj nabavi, PJR d.o.o., Zagreb

11. Ljubanović, B., Britvić-Vetma, B. (2011): Hrvatsko pravo javne nabaveusklađenost s pravom EU, Zbornik radova Pravnog fakulteta u Splitu, 48, 2/2011

12. Maletić, I., Kosor, K., Copić, M., Ivanković Knežević, K., Zrinušić, N., Bešlić, B., Bukovac, S., Kulakowski, N., Karačić, M., Rajaković, M., Tufekčić, M., Petričko, I., Valić, S. (2016): EU projekti - od ideje do realizacije, TIM4PIN d.o.o., Zagreb

13. Ministarstvo gospodarstva, poduzetništva i obrta (2016): Vodič kroz nova pravila javne nabave, http://www.javnanabava.hr/userdocsimages/Informativni $\% 20$ Vodic\%20kroz\%20novi\%20Zakon\%20 o\%20javnoj\%20nabavi\%20prosinac\%202016..pdf, [Accessed 3.4.2017.]

14. Narodne novine (2016): Zakon o javnoj nabavi, Narodne novine 120/16 
15. Omondi, R., Munevar J., Lo Piparo Liljegren, C., Nappini, F., Soeltenfuss, J. (2005): A Guide to European Union Funding for NGOs - Accessing Europe's Largest Donor, ECAS - European Citizens Action Service, Brussels

16. Portal javne nabave (2016): Postupci javne nabave velike vrijednosti od 18. travnja 2016. - izravan učinak direktive 2014/24/EU I 2014/25/EU, http://www. javnanabava.hr/default.aspx?id=5107, [Accessed 10.12.2016.]
17. Portal javne nabave (2017): Sprječavanje korupcije i sukoba interesa, http:// javnanabava.hr/default.aspx?id=3426, [Accessed 3.4.2017.]

18. Tufekčić, M., Tufekčić, Ž. (2013): EU politike \& fondovi 2014 - 2020, Plavi partner d.o.o., Zagreb

19. Zrinušić, A. (2014): Javna nabava, BIZ direct, 49, god.

\section{IZAZOVI JAVNE NABAVE U PROJEKTIMA FINANCIRANIM IZ SREDSTAVA EU-A}

\section{Sažetak}

Članstvo u Europskoj Uniji zahtijeva prilagodbu EU projekata pravilima strukturnih fondova, ali i prihvaćanje pravnih propisa, a što djeluje i na provedbu javne nabave u projektima, financiranih od strane EU-a. Svaki uspješni prijavitelj, kojemu je potrebna nabava proizvoda, usluga $i$ vanjske suradnje određenih vrijednosti, mora poštovati načela javne nabave. Nepravilnosti u procesu nabave mogu prouzročiti i probleme u vraćanju sredstava EU-a, pa čak $i$ nekoliko godina nakon završetka projekta. Stoga su znanje $i$ točna provedba javne nabave temeljni preduvjet za točnu provedbu svakog projekta.
Kako bi se dobila informacija o trenutnom apsorpcijskom kapacitetu organizacija od kojih se zahtijeva javna nabava te utvrdile ključne zapreke, s kojima se suočavaju dionici javne nabave, provedeno je istraživanje na uzorku od 30 hrvatskih organizacija - obveznika javne nabave. Rezultati istraživanja ukazuju na nisku kvalitetu javne nabave u implementiranim projektima, a što često dovodi do financijskih ispravaka, neodobravanja projektnih izvješća, itd.

Ključne riječi: javna nabava, PRAG, Zakon o javnoj nabavi, EU projekti, EU fondovi, financijske ispravke 
